DOI: $10.17805 / z p u .2017 .2 .3$

\title{
Голем, Робокоп и другие: российская молодежь о киборгах *
}

\author{
В. А. ЛУКОВ \\ МОСКОВСКИЙ ГУМАНИТАРНЫЙ УНИВЕРСИТЕТ
}

В статье рассматриваются некоторые результаты эмпирического исследования «Социальные ожидания и опасения развития технологий “улучшения" человека в молодежной среде». Оно проводилось в 2016 г. среди студентов российских городов: Москвы, Анадыря, Белгорода, Братска, Екатеринбурга, Иркутска, Кызыла, Новосибирска, Орла, Элисты, Якутска по квотной выборке. Респонденты представляли собой студентов (по большей части), которые были разделены на две подгруппы: будущие медики, биологи, биотехнологи, а также представители профессий, получаемых или уже полученных в областях, непосредственно не связанных с тематикой «улучшения» человека.

В основном вопросы исследования были сориентированы на позиции трансгуманизма, сформулированные как несколько фантастические для 1960-1970-х годов, но вполне решаемые даже тогда. В настоящее же время эти вопросы исходят из возможности и допустимости при помощи биотехнологий XXI в. так изменить человека, что его природные черты коренным образом преобразятся, он приобретет такие особенности биологической и психической жизни, которые сделают его бессмертным, всесильным, сверхумным и т. д., т. е. более совершенным, чем его создала природа в процессе эволюции живых форм. В исследовании, в частности, ставились вопросы о знании респондентами и их ближайшим кругом сверстников популярных персонажей разных веков, обладающих свойствами киборгов. Предполагалось, что старые версии киборгов в основном неизвестны, новые же версии воспринимаются как нормальные.

Но данные показали более сложную картину, которая представлена в соответствующей интерпретации, учитывающей тезаурусные конструкции молодых людей, проживающих в различных регионах современной России. Молодежь пользуется разными источниками

* Исследование выполнено по гранту Российского научного фонда (проект № 15-18-30057). The research was supported by a Russian Science Foundation grant (project No. 15-18-30057). 
технологий «улучшения» человека, однако в основном не показывает разницы в отношении к этим технологиям. Здесь действуют не профессиональные, а социокультурные факторы. Молодежь различных территорий России ничем особенно не отличается в оценке технологий «улучшения» человека. Будущие биологи и медики примерно так же видят пути изменения человека, как и получающие (получившие) иное образование. Молодые считают себя недостаточно компетентными, чтобы взять на себя тяготы «улучшения» человека. Тем не менее около трети опрошенных признают особую роль молодежи в перспективах становления нового человека.

Ключевые слова: трансгуманизм; биосоциология; молодежь; генная инженерия; киборг; Голем; Франкенштейн; профессор Доуэль; Терминатор; Робокоп

\section{ВВЕАЕНИЕ}

XXI в. делает некоторые фантастические идеи прошлого, даже недалекого, относящиеся к ХХ в., вполне реальными. Это относится к воздухоплаванию, автомобилестроению, архитектуре мегаполисов, многому другому, что составляет повседневность человека, а также и к самому человеку, его природным свойствам, его восприятию себя и окружающего мира. Аревняя идея бессмертия, нашедшая отражение в мифологии, фольклоре разных народов и в прямых попытках продлить человеческую жизнь при помощи снадобий, эликсиров, наложения рук и т. А., приобретает черты биотехнологии и достигается и на биологическом, и на психологическом уровнях. Появилось даже понятие «улучшение» человека», которое и обозначает изменение человеческой природы, какое дает не система воспитания, как у Т. Мора, Т. Кампанеллы, других утопистов, мечтавших о «правильной» молодежи, французских просветителей, руссоистов, российских воспитателей советского времени, закладывавших основы «нового» человека. Речь идет именно о биологических изменениях, которые сделают человека лучше, чем определено природой. Б. Г. Юдин пишет, что английское слово enbancement на русский язык может переводиться по-разному: «Зачастую его переводят как совершенствование... термин “улучшение” в ценностном отношении более нейтрален, чем термин “совершенствование” (Юдин, 2016: 19). Правда, Б. Г. Юдин нередко берет слово «улучшение» в кавычки, подчеркивая этим, что не все соответствующие (по замыслу) воздействия ведут в реальности к более совершенному человеку.

В значительной степени это относится к киборгам - гибридам человека и машины, кибернетическим организмам, понимаемым с 1960-х годов как лучшая модель человека, приспособленного к жизни вне земного пространства. В 1960 г., когда в статье Манфреда Э. Клайнса, больше известного к тому времени своими работами по музыковедению, и психолога Натана С. Клина прозвучало впервые слово «киборг» (Clynes, Kline, 1960), а оно было вынесено в название статьи, авторы так разъясняли смысл нововведения: «Изменения функций организма человека для удовлетворения требований внеземной среды будет более логично, чем предоставление ему земных условий в Космосе... Одной из возможностей являются построенные подобно организму системы, обеспечивающие самоуправляемый контроль, осуществляемый человеком без участия его сознания» (там же: 26). Таким образом, киборг в своем основании не связан с литературным героем Эдгара По (как оказалось, пародией) - красавцем, любимцем женщин бревет-бригадным генералом Ажоном А. Б. В. Смитом, на самом деле потерявшим в войне с индейцами почти все части тела, замененные протезами (The Man That Was Used Up, 1839), хотя многими именно «Человек, изрубленный на куски» (как у нас принято переводить название сатиры Э. По) считается первым рассказом о киборге, что вряд ли обоснованно. Это относится и к подобным персонажам в художественной 
литературе других стран и разных времен (например, A Beautiful Young Nymph Going to Bed Аж. Свифта, 1731). Киборг, напротив, наилучшим образом приспособлен к изменившимся реалиям. Авторы, определяя его, писали: «Киборг сознательно включает экзогенные компоненты расширения саморегулирования контрольной функции организма для того, чтобы адаптировать его к новым условиям» (там же: 27).

Что по этому поводу думает российская молодежь, получающая или уже получившая высшее образование?

В социологическом исследовании «Социальные ожидания и опасения развития технологий “улучшения” человека в молодежной среде», проведенном в 2016 г. по нашему инструментарию под руководством проф. А. И. Ковалевой (над исследованием работали В. А. Гневашева, Ч. К. Аамажаа, С. В. Ауков, Е. Г. Зима), собраны данные о мнениях студентов одиннадцати российских городов - Москвы, Анадыря, Белгорода, Братска, Екатеринбурга, Иркутска, Кызыла, Новосибирска, Орла, Элисты, Якутска $(\mathrm{N}=731)$. В режиме экспертного опроса и наблюдения по той же группе вопросов исследование проводилось также среди участников Международной научной школы для молодежи «Концепции постчеловека в философии и технонауке», проходившей на базе отдыха «Нежеголь» Белгородского государственного национального исследовательского университета (19-23 мая 2016 г.). Российские молодые участники школы приехали из Белгорода, Волгограда, Воронежа, Курска, Аипецка, Москвы, Перми, Саратова, Санкт-Петербурга. Исследование, таким образом, в основном проводилось в частях России, не связанных в молодом поколении региональными обобщениями и общими формулами. Важным параметром исследования было разделение молодых людей на, с одной стороны, биологов и медиков, т. е. тех, кто сейчас или в будущем непосредственно связан в своих регионах с «улучшением» человека, и с другой стороны, всех остальных российских молодых людей, получающих или уже получивших высшее образование, т. е. тех, кто уже приобрел или приобретет в дальнейшем профессии инженерно-технического или (в исследовании это представлено чаще) гуманитарного склада, непосредственно не связанного с задачами «улучшения» человека.

Аве подгруппы дали статистически значимую разницу в ответах на вопросы, касающиеся источников знаний о проблеме «улучшения» человека, хотя это не наблюдалось применительно к большинству содержательных параметров (Иуков, 2016). Некоторые сопоставления могут быть оценены как незначимые по выделенному (фактически профессиональному) признаку, хотя есть значимые различия по другим параметрам, например по полу. Это касается, в частности, киборгизации как способа «улучшения» человека. Киборгизация (как это и обозначено в трансгуманизме) трактовалась как улучшение тела имплантами. Картина мнений молодежи представлена в табл. 1.

Аля нас здесь важно не столько раздичие киборгизации в предпочтениях первой и второй подгрупп, сколько общее для российской молодежи умеренное отношение к превращению человека в киборга: лишь 44\% выразили одобрение этому действию, причем разница по подгруппам невелика, и ожидаемого преувеличения этого фактора в подгруппе биологов и медиков не наблюдается, особенно если считать имплантацию делом вполне обычным с конца XX в. Более того, некоторое увеличение отрицательных ответов есть в первой подгруппе молодежи в сравнении со второй, а доля тех, кто не определился с ответом, в обеих подгруппах одинакова и относительно невелика (14\%).

Причины этого феномена следует видеть не в особом понимании российской молодежью биоэтического смысла киборгизации, а в ориентации на определенный род художественных произведений, более или менее известных молодежи в силу социо- 
Таблища 1

МНЕНИЯ МОАОАЕЖИ О ПЕРСПЕКТИВАХ КИБОРГИЗАЦИИ

Table 1

YOUNG PEOPLE'S OPINION ON THE PROSPECTS OF CYBORGIZATION

\begin{tabular}{|c|c|c|c|c|c|c|}
\hline \multirow{2}{*}{\multicolumn{2}{|c|}{$\begin{array}{l}\text { По какой спечиальности (направлению } \\
\text { подготовки) Вы получили (получаете } \\
\text { в настоящее время) высшее образование? }\end{array}$}} & \multicolumn{5}{|c|}{ Улучшение тела имплантами (киборгизачия) } \\
\hline & & \multirow{2}{*}{$\Delta a$} & \multirow{2}{*}{$\begin{array}{r}\mathrm{Hem} \\
72\end{array}$} & \multirow{2}{*}{$\begin{array}{c}\text { Не знаю } \\
22\end{array}$} & \multirow{2}{*}{ 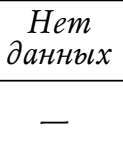 } & \multirow{2}{*}{$\begin{array}{r}\text { Bcero } \\
156\end{array}$} \\
\hline Биолог, медик & абс & & & & & \\
\hline & $\%$ & $40 \%$ & $46 \%$ & $14 \%$ & - & $100 \%$ \\
\hline \multirow[t]{2}{*}{ Аругие специальности } & абс & 248 & 237 & 78 & 1 & 564 \\
\hline & $\%$ & $44 \%$ & $42 \%$ & $14 \%$ & $0 \%$ & $100 \%$ \\
\hline \multirow[t]{2}{*}{ Нет данных } & абс & 10 & - & 1 & - & 11 \\
\hline & $\%$ & $91 \%$ & - & $9 \%$ & - & $100 \%$ \\
\hline \multirow[t]{2}{*}{ Bcero } & абс & 320 & 309 & 101 & 1 & 731 \\
\hline & $\%$ & $44 \%$ & $42 \%$ & $14 \%$ & $0 \%$ & $100 \%$ \\
\hline
\end{tabular}

культурных оснований, иначе говоря, в силу тезаурусных ориентаций. Мы здесь

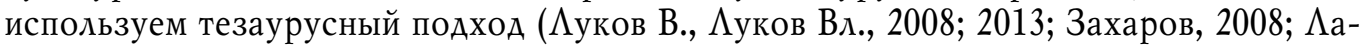
мажаа, 2012), в основе которого лежит трактовка тезауруса как субъектно организованного знания - не от общего к частному (что характерно для построения системы объективного знания в форме науки), а от «своего» к «чужому». На этом основании построена и тезаурусная концепция молодежи (Ауков, 2012).

В настоящей статье мы выявляем тезаурусные ориентации, исследуя отношение российской молодежи к киборгизации через ее представления о таких персонажах фантастических произведений, как Голем, Франкенштейн, профессор Аоуэль, Терминатор, Робокоп.

\section{ПРЕАВАРИТЕАЬНЫЕ ААННЫЕ}

В 2015 г. мы вместе со студентом А. В. Павловым провели пилотажное исследование относительно знания представителями разных возрастных групп ( $\mathrm{N}=100)$ киборгов или подобных им персонажей из литературы прошлого, а именно Голема и профессора Аоуэля, а также киногероев Терминатора и Робокопа. Мы сделали следующие выводы относительно распространенности в повседневном сознании представителей разных поколений четырех образов, которые отражают проекты конструирования человека, популярные в свое время. «Первый такой образ - Голем, искусственный великан из глины для исполнения разных черновых работ, трудных поручений, которого, по пражской легенде XVII в., создал праведный раввин защиты еврейского народа. Среди тех, кому больше 40 лет, это имя известно примерно одной трети опрошенных. А среди 16-20-летних - ни одному. Имя профессора Аоуэля знают практически все опрошенные старше 30 лет, поскольку книга Александра Беляева "Голова профессора Аоуэля"... была одной из самых популярных в советскую эпоху. Но 16-20-летние практически не знают ни этого литературного образа, ни характера экспериментов по конструированию человека, описанных в этой книге. Зато молодые участники опроса хорошо знают имена таких киногероев, как 
Робокоп и Терминатор. А в старшей группе это уже совсем не так» (Иуков, Павлов, 2015: Электронный ресурс). Проведенный в предварительном порядке опрос показал возможное влияние на концепции «улучшения» человека знаний лиц разного возраста, выдвигающих такие концепции и принимающих их как должное.

Предварительные данные уточнены в базовом исследовании 2016 г., но оно проведено только среди молодежи (в большинстве до 20 лет) и не позволяет сравнивать опрошенных с большими дистанциями возраста. В то же время применительно к молодежи оно уточняет тезаурусные ориентации. Они представлены ниже по пяти фантастическим персонажам.

\section{ГОАЕМ}

Мы уже отмечали, что Голем - глиняный великан-получеловек, легенда о котором сложилась в Праге в XVII в., а вероятно, и раньше, в XIV в. В базовом исследовании 2016 г. отношение к этому фантастическому персонажу выглядит следующим образом (табл. 2).

Предварительное исследование дает несколько иную картину. Все же Голем, согласно базовому исследованию 2016 г., считается хорошо известным примерно трети в кругу молодых людей (почти нет региональной разницы по этому вопросу), причем в равной степени в первой и второй подгруппах, но около половины опрошенных затруднились с ответом. Некоторые комментарии здесь необходимы.

Голем - почти забытый мистический персонаж. Но в 2000-е годы Голем снова дает о себе знать новым поколениям разных стран. Исследователи показывают, что здесь используются самые простые параллели. Так, под редакцией Р. Гросса и Э. Риделя в 2008 г. на немецком и английском языках во Франкфурте-на-Майне вышла книга, где начиная с обложки Голем в его комиксном выражении (как средстве еврейской памяти)

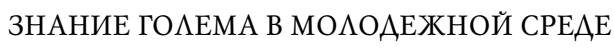

Таблииа 2

YOUNG PEOPLE'S AWARENESS OF GOLEM

Table 2

\begin{tabular}{|c|c|c|c|c|c|c|}
\hline \multirow{2}{*}{\multicolumn{2}{|c|}{$\begin{array}{l}\text { По какой специальности (направлению } \\
\text { подготовки) Вы получили (получаете } \\
\text { в настолщее время) высшее образование? }\end{array}$}} & \multicolumn{5}{|c|}{$\begin{array}{c}\text { Известны ли среди ваших сверстников } \\
\text { литературные и киноперсонажи, которые } \\
\text { отражатот фантастические проектьь } \\
\text { конструирования человека: Голем }\end{array}$} \\
\hline & & \multirow{2}{*}{ 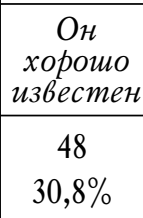 } & \multirow{2}{*}{\begin{tabular}{|c|} 
Он \\
никому не \\
известен \\
36 \\
$23,1 \%$ \\
\end{tabular}} & \multirow{2}{*}{$\begin{array}{c}\text { Трудно } \\
\text { сказать } \\
70 \\
44,9 \%\end{array}$} & \multirow{2}{*}{$\begin{array}{c}\text { Hem } \\
\text { данHьх } \\
2 \\
1,3 \%\end{array}$} & \multirow{2}{*}{$\begin{array}{c}\text { Bcezo } \\
156 \\
100,0 \%\end{array}$} \\
\hline Биолог, медик & $\begin{array}{c}\text { абс } \\
\%\end{array}$ & & & & & \\
\hline Аругие специальности & $\begin{array}{c}\text { абс } \\
\%\end{array}$ & $\begin{array}{c}173 \\
30,7 \%\end{array}$ & $\begin{array}{c}101 \\
17,9 \%\end{array}$ & $\begin{array}{c}285 \\
50,5 \%\end{array}$ & $\begin{array}{c}5 \\
0,9 \%\end{array}$ & $\begin{array}{c}564 \\
100,0 \%\end{array}$ \\
\hline Нет данных & $\begin{array}{c}\text { абс } \\
\%\end{array}$ & $\begin{array}{c}3 \\
27,3 \%\end{array}$ & $\begin{array}{c}2 \\
18,2 \%\end{array}$ & $\begin{array}{c}6 \\
54,5 \%\end{array}$ & - & $\begin{array}{c}11 \\
100,0 \%\end{array}$ \\
\hline Всего & $\begin{array}{c}\text { абс } \\
\%\end{array}$ & $\begin{array}{c}224 \\
30,6 \%\end{array}$ & $\begin{array}{c}139 \\
19,0 \%\end{array}$ & $\begin{array}{c}361 \\
49,4 \%\end{array}$ & $\begin{array}{c}7 \\
1,0 \%\end{array}$ & $\begin{array}{c}731 \\
100,0 \%\end{array}$ \\
\hline
\end{tabular}


сопоставляется с Суперменом (Gross, Riedel, 2008). Е. Байер, автор обстоятельной монографии о Големе как персонаже, проделавшем путь от пражского мифа XIV в. до пост-Холокостовского художественного творчества, опираясь на публикацию Аана Билевски в «Нью Йорк Таймс» 2009 г., где Голем объявлен монстром современного кризиса, на ряд других публикаций, восклицает: «Голем возвращается!» (Baer, 2012: 1).

Но особенно выразительна постановка переосмысленной инсценировки романа начала XX в. Г. Мейеринка «Голем» на Зальцбургском фестивале 2014 г. (примерно 100 лет спустя после триумфа этой инсценировки в Европе, тогда охваченной переживаниями Первой мировой войны) английской труппой Сьюзан Андрейд: здесь мультипликационный Голем, погибая от переизбытка информации, становится сначала мобильным устройством, контролирующим контакты людей, а затем и чипом в ухе (Mayer, 2014).

Российская молодежь еще, в сущности, не знает такого Голема, но отдельные черты нового фэнтези-героя все же проникают в ее повседневность, в том числе в виде персонажей компьютерных игр, например «Террарии» - игры жанра «песочница» (sandbox) в стиле 2D-платформера (http://ru.terraria.wikia.com/wiki/). В то же время, как показывают беседы с молодежью разных регионов России, Голем даже в этом обновленном виде не воспринимается как киборг и скорее похож на орка Толкиена, который более понятен, чем монстр из глины, обладающий зачатками сознания.

\section{ФРАНКЕНШТЕЙН}

В 1818 г. Мэри Шелли написала роман «Франкенштейн, или Современный Прометей» об ученом Викторе Франкенштейне, создавшем бессмертного монстра (который плакал у трупа Виктора и искал смерти), позже названного по имени его создателя Франкенштейном. Роман М. Шелли написан в духе предромантизма (Ауков, 2006) и совершенно не напоминает современные фэнтези. С 1910 по 2015 г. было создано 26 фильмов и телефильмов, по крайней мере 7 комиксов, 7 музыкальных спектаклей, 4 компьютерных игры о Франкенштейне (Frankenstein: Электронный ресурс; Франкенштейн: Электронный ресурс). Он лучше известен молодежи, о чем свидетельствует табл. 3 (см. с. 48).

Франкенштейн, несомненно, лучше известен российской молодежи, особенно представителям второй подгруппы, хотя, по существу, является Големом, только созданным не из глины и камней, а из остатков человеческих тел, и не каббалистом в результате тайных заклинаний, а ученым в результате применения научных знаний. О Мэри Шелли, ее романе, встречающихся там матросах и прочем, не имеющем отношения к сюжету о искусственно созданном монстре, молодежи толком ничего не известно, Франкенштейн больше похож на киборга в земных условиях, и больше заметно его бессмертие, чем другие черты. Мы имеем дело не с персонажем романа начала XIX в., а с примерным представлением о его культе на основе фрагментов фильмов, комиксов и компьютерных игр, но даже и в әтом случае он известен не всем, хотя бы по имени, и около $1 \%$ опрошенных считают, что он в их окружении никому не известен.

\section{ГОАОВА ПРОФЕССОРА АОУЭАЯ}

В представлении о киборгах нашлось место и для русского писателя-фантаста Александра Романовича Беляева (1884-1942). Наибольшее значение в этом плане имеет книга «Голова профессора Аоуэля», написанная первоначально как рассказ, опубликованный в 1924 и 1925 г., затем приобретшая черты романа, опубликованного в 1937 г. (Мяпунов, 1967). Книга хорошо известна старшему поколению, снятый по ее мо-

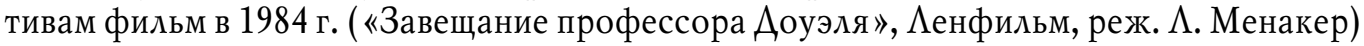


ЗНАНИЕ ФРАНКЕНШТЕЙНА В МОАОАЕЖНОЙ СРЕАЕ

Таблица 3

YOUNG PEOPLE'S AWARENESS OF FRANKENSTEIN

Table 3

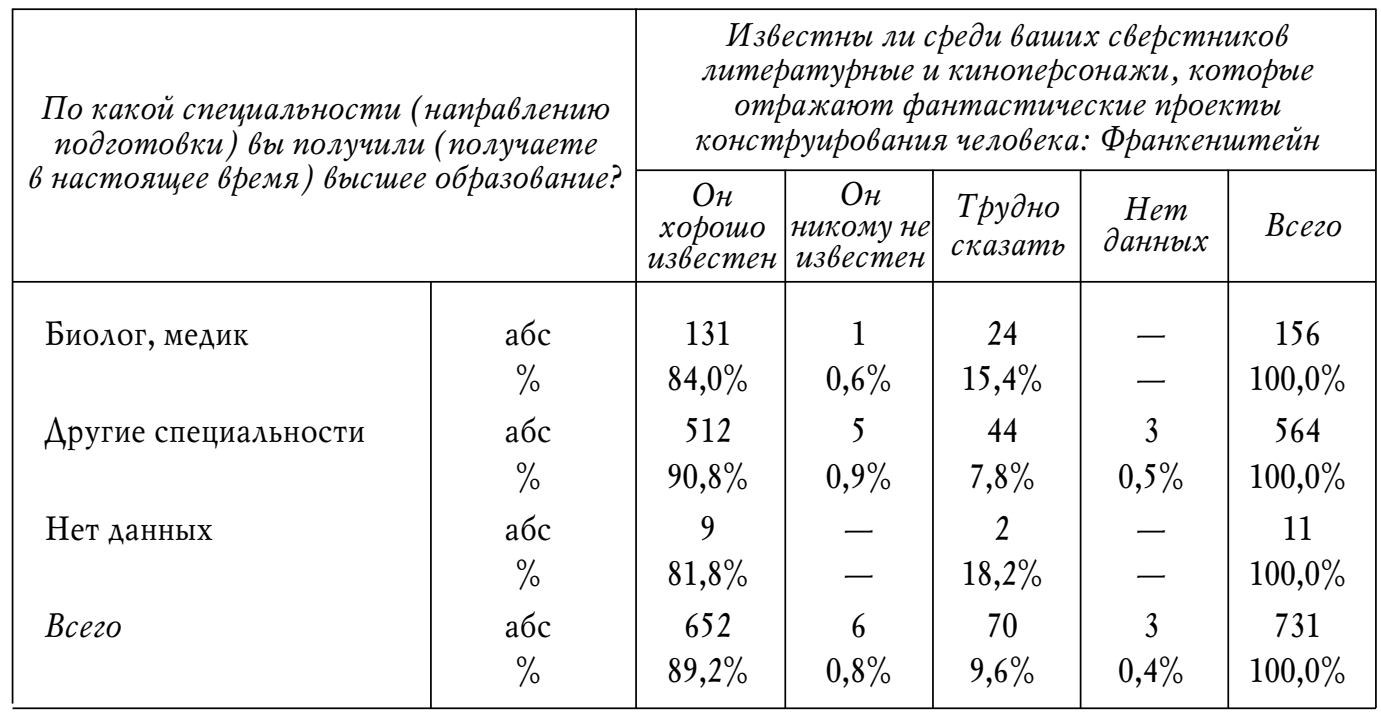

неудачен, соответствующих компьютерных игр нет, что отодвинуло произведение Беляева от молодого поколения. Отношение опрошенной молодежи к книге представлено в табл. 4.

Книга А. Р. Беляева известна примерно четверти в ближайшем кругу сверстников респондентов, и примерно такое же число сверстников о голове профессора Аоуэля ничего не слышали. Нет определенного ответа в половине случаев, что означает чаще всего незнание книги респондентами.

В 1920-х годах стремление к сохранению жизни частей тела было движущей науку идеей. Особенно в опытах такого рода продвинулся вперед С. С. Брюхоненко, изолировавший голову собаки и давший ей вторую жизнь, используя аппарат искусственного кровообращения (Брюхоненко, Чечулин, 1926). В этот период активно развивалась евгеника, но установка на создание нового человека в минимальной степени в то время связывается с биотехнологическим вмешательством в его природу, делается расчет на методы селекции. Этот подход в своей основе базируется на природных свойствах живых организмов. Именно в этом духе видели перспективы улучшения человеческой породы русские представители евгеники Н. К. Кольцов, Ю. А. Филипченко и др. (Кольцов, 1922; Филипченко, 1924) При этом понимание ими «улучшения человеческой породы» исходило из особой деликатности предмета проектирования, «преждевременности» каких-либо насильственных действий в такой селекции (например, путем принудительной стерилизации). Как отмечал Н. К. Кольцов, «наука об улучшении

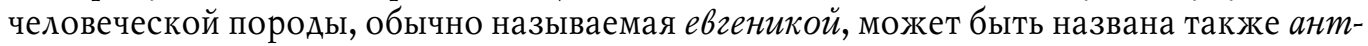
ропотехнией, так как она является не более как отделом зоотехники... разведение новой породы или пород человека подчиняется тем же законам наследственности, как и у других животных... единственным методом этого разведения может служить лишь подбор производителей, а отнюдь не воспитание людей в тех или иньх услови- 
ЗНАНИЕ КНИГИ О ПРОФЕССОРЕ АОУЭАЕ В МОАОАЕЖНОЙ СРЕАЕ

Таблища 4

YOUNG PEOPLE'S AWARENESS OF THE BOOK ABOUT PROFESSOR DOWELL

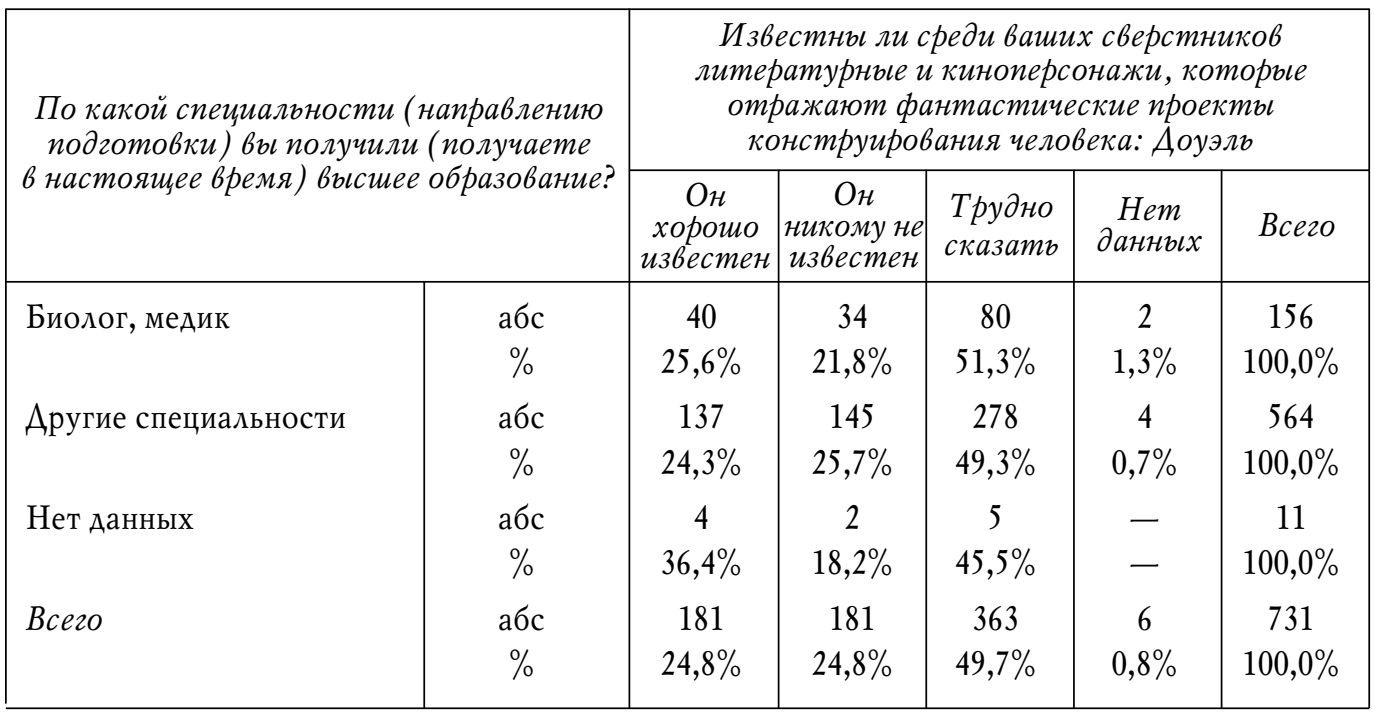

ях, или те или иные сочиальные реформы или перевороты...» (Кольцов, 1922: 8; курсив источника. - B. А.). В то же время он утверждал, что «мы не можем ставить опытов, мы не можем заставить Нежданову выйти замуж за Шаляпина только для того, чтобы посмотреть, каковы у них будут дети, мы не можем ставить по определенному плану опытов, а должны ограничиваться простым наблюдением...» (там же).

Сложность «улучшения» жизни и многовариантость решений в молодежной среде не учитывают евгенических селекционных действий и более ориентированы на имплантацию человекоподобных органов, что показывает достаточно широкое принятие ею персонажей типа Терминатора и Робокопа.

\section{ТЕРМИНАТОР}

Сравнительно хорошо молодежи известен «Терминатор» - фильм Аж. Камерона, снятый в 1984 г. и благодаря Арнольду Шварценеггеру приобретший популярность (в 1991 г. Камерон снял «Терминатор-2», в 2003 г. снят «Теминатор-3», в 2008 г. - телесериал, 2009 г. - фильм «Терминатор: Аа придет Спаситель», в 2015 г. - «Терминатор: Генезис» и т. А.).

О популярности Терминатора в молодежной среде России свидетельствуют следующие данные (табл. 5, с. 50).

Как видим, это хорошо известный молодежи персонаж, что во многом определяется частым показом фильмов киносаги по многим программам российского телевидения. Особых региональных отличий в силу этого нет.

Смысл фильма в постчеловеческом мире передает монография А. Аинелло, вышедшая в 2013 г. (Dinello, 2013). Аинелло называет свою книгу «Технофобия!», ставя перед героями «улучшения» человека дилемму «технорай» или «техноад». Автор исходит из того, что первоначально человеческие тела будут усовершенствованы с помощью 
ЗНАНИЕ ОБРАЗА ТЕРМИНАТОРА В МОАОАЕЖНОЙ СРЕАЕ

Таблица 5

YOUNG PEOPLE'S AWARENESS OF TERMINATOR'S IMAGE

Table 5

\begin{tabular}{|c|c|c|c|c|c|c|}
\hline \multirow{2}{*}{\multicolumn{2}{|c|}{$\begin{array}{l}\text { По какой спечиальности (направлению } \\
\text { подготовки) вь получили (получаете } \\
\text { в настоящее времл) вьстее образование? }\end{array}$}} & \multicolumn{5}{|c|}{$\begin{array}{c}\text { ИзВестны ли среди ваших сверстников } \\
\text { литературные и киноперсонажи, которые } \\
\text { отражают фантастические проекть } \\
\text { конструирования человека: Терминатор }\end{array}$} \\
\hline & & \multirow{2}{*}{$\begin{array}{c}\begin{array}{c}\mathrm{OH} \\
\text { xорошо } \\
\text { uзвестен }\end{array} \\
131 \\
84,0 \%\end{array}$} & \multirow{2}{*}{$\begin{array}{c}\begin{array}{c}\text { Он } \\
\text { никому не } \\
\text { известен }\end{array} \\
1 \\
0,6 \%\end{array}$} & \multirow{2}{*}{$\begin{array}{c}\text { Трудно } \\
\text { сказать }\end{array}$} & \multirow{2}{*}{$\begin{array}{c}\begin{array}{c}\text { Hem } \\
\text { данных }\end{array} \\
- \\
-\end{array}$} & \multirow{2}{*}{$\begin{array}{c}\text { Bcezo } \\
156 \\
100,0 \%\end{array}$} \\
\hline Биолог, медик & $\begin{array}{c}\text { абс } \\
\%\end{array}$ & & & & & \\
\hline Аругие специальности & $\begin{array}{l}\text { абс } \\
\%\end{array}$ & $\begin{array}{c}529 \\
93,8 \%\end{array}$ & $\begin{array}{c}4 \\
0,7 \%\end{array}$ & $\begin{array}{c}28 \\
5,0 \%\end{array}$ & $\begin{array}{c}3 \\
0,5 \%\end{array}$ & $\begin{array}{c}564 \\
100,0 \%\end{array}$ \\
\hline Нет данных & $\begin{array}{c}\text { абс } \\
\%\end{array}$ & $\begin{array}{c}11 \\
100,0 \%\end{array}$ & - & - & $\begin{array}{l}- \\
-\end{array}$ & $\begin{array}{c}11 \\
100,0 \%\end{array}$ \\
\hline Всего & $\begin{array}{c}\text { абс } \\
\%\end{array}$ & $\begin{array}{c}671 \\
91,8 \%\end{array}$ & $\begin{array}{c}5 \\
0,7 \%\end{array}$ & $\begin{array}{c}52 \\
7,1 \%\end{array}$ & $\begin{array}{c}3 \\
0,4 \%\end{array}$ & $\begin{array}{c}731 \\
100,0 \%\end{array}$ \\
\hline
\end{tabular}

генетических манипуляций и слияния человека и машины, а затем человеческие существа будут полностью избавлены от оков боли, болезни и даже смерти. Техноутопическое будущее, таким образом, спасет человечество. Но есть и другая сторона: темное будущее будет характеризоваться прежде всего безумными учеными, неистовствующими роботами, клонами-убийцами и неконтролируемыми вирусами. Постчеловеческая эволюция знаменует собой начало конца человеческой свободы, ценностей и идентичности. Аинелло рассматривает робототехнику, бионику, искусственный интеллект, виртуальную реальность, биотехнологию, нанотехнологию и другие значимые научные достижения, обобщая текущее состояние каждой технологии и представляя соответствующие реакции в научной фантастике. Автор книги опирается на фильмы, программы телевидения, замыслы книг и компьютерных игр, а также утверждает, что фантасты функционируют как ценный корректив, своего рода противовес к технологическому господству, противодействие техношумихе, ее нацеленности на прибыль. Пафос книги и состоит в призыве к контролю людей над технологией.

Из бесед с молодежью вытекает, что это противопоставление технологии и фантастики не замечено, и Терминатор подкупает скорее физической силой, а фильмы о нем выступают как блокбастеры, т. е. высокобюджетные фильмы-развлечения с напряженным сюжетом и с планированием значительных доходов от кинопоказов.

Более определенно противопоставление технологии и фантастики ощущается в «Робокопе», это заметно и по беседам с молодежью.

\section{РОБОКОП}

«Робокоп», «Робот-полицейский» - фильм Пола Верховена, поставленный в 1987 г. под названием «RoboCop» со слоганом на афишах «Part man. Part machine. All cop. The future of law enforcement» («Частью человек. Частью машина. В целом же поли- 
цейский. Будущее охраны правопорядка»). Этот фильм был воспринят как фантастический и первоначально (до выхода фильма) характеризовался в печати через пересказ его фабулы (King, 1986). Но позже, после успеха фильма возникает более серьезное понимание его биотехнологического смысла (Markoff, 1990). Коммерческий успех и высокая популярность фильма (включая две номинации на «Оскар») определили судьбу нескольких сиквелов фильма, созданы четыре полнометражных фильма, несколько мульт- и телесериалов, видеоигр и т. д.

В американской прессе отмечалось, что хотя «Робокоп» замышлялся «просто как “футуристическая фантазия” на тему правоохранительных органов», в настоящее время SWART-команды имеют в своем арсенале робокопно-подобные инструменты» (Garrett, 2010: Электронный ресурс).

Какова реакция на фильм «Робокоп» у российской молодежи? Некоторое представление об этом дает табл. 6.

Мы замечаем в первой подгруппе меньший интерес к данному образу, чем во второй. Идея, что киборг, собранный из остатков человека и начиненных компьютерами машинных деталей, заменит в некоторых сферах человека, не является широко распространенной в молодежной среде России, о чем свидетельствует табл. 7 (см. с. 52).

Российская молодежь не ориентирована на такую охрану правопорядка и на такое ведение военных действий, которые строились бы на киборгах. Около половины представителей первой группы $(46,8 \%)$ и примерно столько же представителей второй группы $(48,2 \%)$ не считают этот путь возможным. Разумеется, положительные ответы в двух подгруппах, в первую очередь несомненные, надо учитывать. Пока их относительно немного (10,9 и 16,3\%), но их основная часть сосредоточена в младших молодежных группах, а значит, через короткое время понимание киборга как наилучшего полицейского и воина станет привычным и у нас.

ЗНАНИЕ ОБРАЗА РОБОКОПА В МОАОАЕЖНОЙ СРЕАЕ

Таблича 6 Table 6

YOUNG PEOPLE'S ATTITUDE TOWARDS CYBORGS IN THE POLICE, ARMY, ETC.

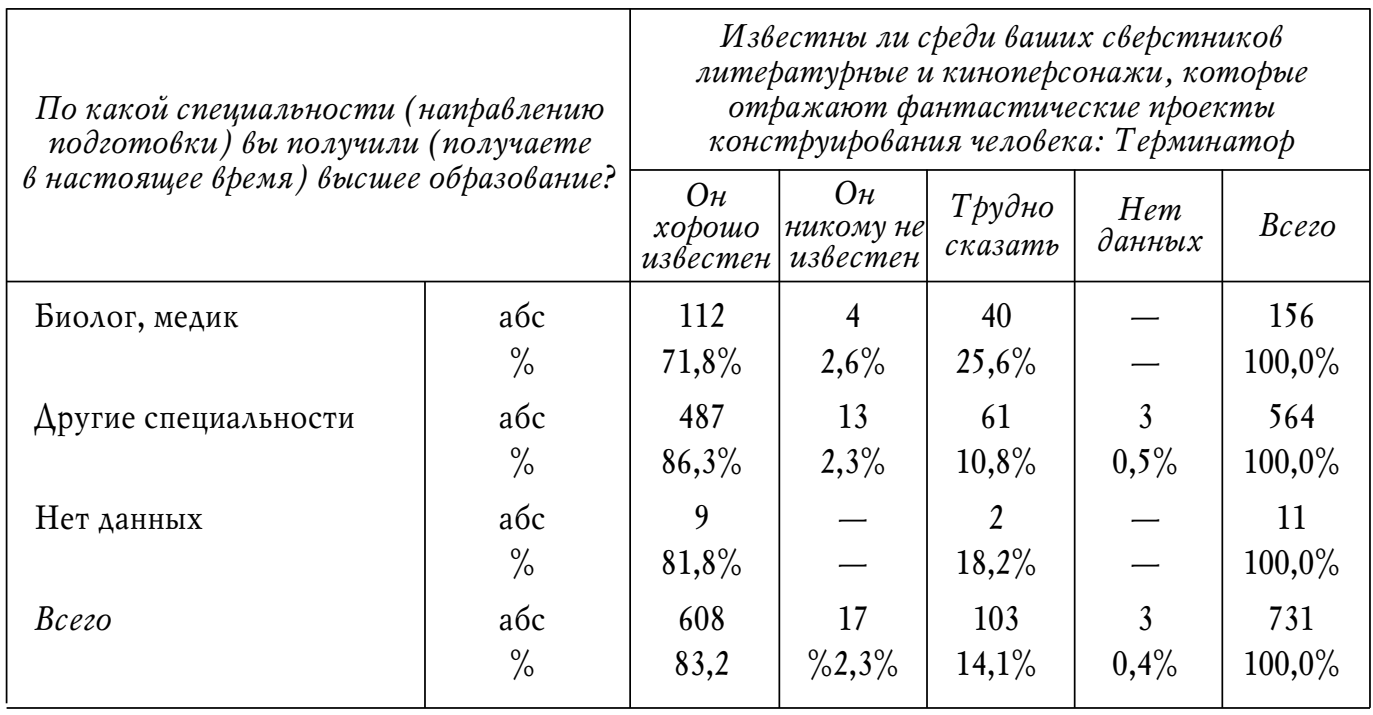


ОТНОШЕНИЕ МОАОАЕЖИ К КИБОРГАМ В ПОАИЦИИ, АРМИИ И Т.А.

Таблица 7

YOUNG PEOPLE'S ATTITUDE TOWARDS CYBORGS IN THE POLICE, ARMY, ETC.

\begin{tabular}{|c|c|c|c|c|c|c|c|}
\hline \multirow{2}{*}{\multicolumn{2}{|c|}{$\begin{array}{c}\text { По какой специальности (на- } \\
\text { правлению подготовки) вы по- } \\
\text { лучили (получаете } \\
\text { в настоящее время) высшее об- } \\
\text { разование? }\end{array}$}} & \multicolumn{6}{|c|}{$\begin{array}{c}\text { Человека в некоторых сферах должны заменить киборги с } \\
\text { встроенными программами действия. Это касается поли- } \\
\text { чии, армии, персонала режимных предприятий и вредных для } \\
\text { здоровья производств }\end{array}$} \\
\hline & & $\Delta a$ & $\begin{array}{l}\text { Cкорее } \\
\text { да чем }\end{array}$ & Трудно & $\begin{array}{c}\text { Скорее } \\
\text { нет чем }\end{array}$ & Hem & Bcero \\
\hline Биолог, медик & $\begin{array}{l}\text { абс } \\
\%\end{array}$ & $\begin{array}{c}17 \\
10,9 \%\end{array}$ & $\begin{array}{c}29 \\
18,6 \%\end{array}$ & $\begin{array}{c}37 \\
23,7 \%\end{array}$ & $\begin{array}{c}20 \\
12,8 \%\end{array}$ & $\begin{array}{c}53 \\
34,0 \%\end{array}$ & $\begin{array}{c}156 \\
100,0 \%\end{array}$ \\
\hline Аругие специальности & $\begin{array}{l}\text { абс } \\
\%\end{array}$ & $\begin{array}{c}92 \\
16,3 \%\end{array}$ & $\begin{array}{c}94 \\
16,7 \%\end{array}$ & $\begin{array}{c}117 \\
20,7 \%\end{array}$ & $\begin{array}{c}100 \\
17,7 \%\end{array}$ & $\begin{array}{c}161 \\
28,5 \%\end{array}$ & $\begin{array}{c}564 \\
100,0 \%\end{array}$ \\
\hline Нет данных & $\begin{array}{l}\text { абс } \\
\%\end{array}$ & $\begin{array}{c}1 \\
9,1 \%\end{array}$ & $\begin{array}{c}3 \\
27,3 \%\end{array}$ & $\begin{array}{c}3 \\
27,3 \%\end{array}$ & $\begin{array}{c}3 \\
27,3 \%\end{array}$ & $\begin{array}{c}1 \\
9,1 \%\end{array}$ & $\begin{array}{c}11 \\
100,0 \%\end{array}$ \\
\hline Всего & $\begin{array}{c}\text { абс } \\
\%\end{array}$ & $\begin{array}{c}110 \\
15,0 \%\end{array}$ & $\begin{array}{c}126 \\
17,2 \%\end{array}$ & $\begin{array}{c}157 \\
21,5 \%\end{array}$ & $\begin{array}{c}123 \\
16,8 \%\end{array}$ & $\begin{array}{c}215 \\
29,4 \%\end{array}$ & $\begin{array}{c}731 \\
100,0 \%\end{array}$ \\
\hline
\end{tabular}

\section{ЗАКАЮЧЕНИЕ}

С учетом данных, полученных в базовом эмпирическом исследовании 2016 г., выявляется следующее. Молодые представители первой и второй групп пользуются различными (в том числе профессиональными) источниками технологий «улучшения» человека, однако в основном не показывают разницы в отношении к этим технологиям, о чем свидетельствует их построенные на молодежных тезаурусах мнения о степени распространенности в их среде персонажей из книг, фильмов, компьютерных игр и т. д. тех или иных персонажей-киборгов. Здесь действуют не профессиональные, а социокультурные факторы, как это характерно для социогуманитарного обеспечения проектов персонализированной медицины (Социогуманитарное обеспечение ... , 2014). Существенно, что молодежь различных территорий России ничем особенно не отличается в оценке технологий «улучшения» человека: молодежь различных территорий России не дает оснований для выявления их дистанции (значимости) в оценке технологий «улучшения» человека.

Будущие биологи и медики примерно так же видят пути изменения человека, как и получающие (получившие) иное образование. Исследование показывает, что молодые считают себя недостаточно компетентными, чтобы взять на себя тяготы «улучшения» человека. Тем не менее около трети опрошенных признают особую роль молодежи в перспективах становления нового человека. В этом они во многом будут опираться на художественные образы, пришедшие к ним их книг, фильмов и т. А. о будущем.

\section{СПИСОК АИТЕРАТУРЫ}

Брюхоненко, С. С., Чечулин, С. И. (1926) Опыты по изолированию головы собаки (с демонстрацией прибора) // Труды II Всесоюзного съезда физиологов. $\Lambda$. : Главнаука. С. 289-290. 
Захаров, Н. В. (2008) Шекспиризм русской классической литературы: тезаурусный анализ М. : Изд-во Моск. гуманит. ун-та. 320 с.

Кольцов, Н. К. (1922) Улучшение человеческой породы // Русский евгенический журнал. T. 1. Вып. 1. С. 1-27.

Аамажаа, Ч. К. (2012) Тезаурусный подход в тувиноведении // Знание. Понимание. Умение. № 2. C. $38-45$.

Ауков, В. А. (2012) Теории молодежи: Междисциплинарный анализ. М. : Канон+. 527 с.

$\Lambda$ уков, В. А. (2016) Биотехнологии будущего в оценках молодежи // Рабочие тетради по биоэтике. Вып. 23: Гуманитарный анализ биотехнологических проектов «улучшения» человека : сб. науч. ст./ под ред. Б. Г. Юдина. М. : Изд-во Московского гуманитарного университета. C. $132-255$.

Ауков, В. А., Ауков, Вл. А. (2008) Тезаурусы: Субъектная организация гуманитарного знания. М. : Изд-во Нац. ин-та бизнеса. 784 с.

Ауков, В. А., Ауков, Вл. А. (2013) Тезаурусы II: Тезаурусный подход к пониманию человека и его мира. М. : ИзА-во Нац. ин-та бизнеса. 640 с.

Ауков, В. А., Павлов, А. В. (2015) Конструирование человека в свете тезаурусной концепции молодежи [Электронный ресурс] // Информационный гуманитарный портал «Знание. Понимание. Умение». № 4 (июль-август). URL: http://zpu-journal.ru/e-zpu/2015/4/Lukov_Pavlov_ Constructing-Man/ (дата обращения: 10.02.2017).

Иуков, Вл. А. (2006) Предромантизм. М. : Наука. 683 с.

Аяпунов, Б. В. (1967) Александр Беляев. Критико-биографический очерк. М. : Сов. писатель. 27 с.

Социогуманитарное обеспечение проектов персонализированной медицины: философский аспект (2014) / Белялетдинов, Р. Р., Гребенщикова, Е. Г., Киященко, А. П., Попова и др. // Знание. Понимание. Умение. № 4. С. 12-26.

Филипченко, Ю. А. (1924) Пути улучшения человеческого рода: Евгеника. М. ; А. : Госиздат. 190 c.

Франкенштейн [Электронный ресурс] // Википедия. Свободная энциклопедия. URL: https://ru.wikipedia.org/wiki/Франкенштейн (дата обращения: 15.02.2017).

Юдин, Б. Г. (2016) Технонаука и «улучшение» человека // Epistemology \& Philosophy of Science. T. XLVIII, No. 2. P. 18-27.

Baer, E. R. (2012) The Golem Redux: From Prague to Post-Holocaust Fiction. Detroit : Wayne State University. 240 p.

Clynes, V. E., Kline, N. S. (1960) Cyborgs and Space // Astronautics. Sept. P. 26-27, 74-76.

Dinello, D. (2013) Technophobia!: Science Fiction Visions of Posthuman Technology. Austin : University of Texas Press. 329 p.

Frankenstein [Электронный ресурс]// Wikipedia. The free encyclopedia. URL: https://en.wikipedia.org/wiki/frankenstein (дата обращения: 15.02.2017).

Garrett, R. (2010) Part man. Part machine. All cop. The future of law enforcement [Электронный pecypc]// LEPN. On the Street. May 1. URL: http://www.officer.com/article/10232717/part-manpart-machine-all-cop-the-future-of-law-enforcement (дата обращения: 15.02.2017).

Gross, R., Riedel E. (Hrsg.) (2008) Superman und Golem. Der Comic als Medium jüdischer Erinnerung. Frankfurt : Jüdisches Museum. $48 \mathrm{~s}$.

King, P. (1986) Hollywood turns to Monessen steel plants in filming 'PoboCop' // The Pittsburgh Press. October 29. P. 6.

Markoff, J. (1990) Ideas \& Trends; Art Invents A Jarring New World From Technology // The New York Times: Week in Review. November 25.

Mayer, N. (2014) Ein Golem aus Plastilin geistert durch die Salzburger Festspiele // Die Presse. 24.08. 


\section{GOLEM, ROBOCOP AND OTHERS: RUSSIAN YOUNG PEOPLE ON CYBORGS}

\section{A. LUKOV}

\section{MOSCOW UNIVERSITY FOR THE HUMANITIES}

The paper deals with some results of the empirical study "Social expectations and fears posed by the development of human "enhancement" technologies amidst young people". It was carried out in 2016 among students from the Russian cities of Moscow, Anadyr, Belgorod, Bratsk, Yekaterinburg, Irkutsk, Kyzyl, Novosibirsk, Oryol, Elista, and Yakutsk on the principle of quota sampling. The respondents were mostly students divided into two sub-groups: medical, biology and biotechnology students, as well as students or professionals in fields not connected with the issue of human "enhancement".

The problems of the study were mainly focused on the position of transhumanism, formulated as somewhat fantastical for the 1960-1970s, but quite solvable even back then. Nowadays, these problems proceed from the possibility and acceptability to modify humans by means of the 21st century technology. As a result, human's natural features will radically change; he or she will assume such characteristics of biological and psychological life that will make them immortal, omnipotent superintelligent, etc., i.e. more perfect than created by nature in the course of organic evolution. The study especially questioned how well the respondents and their closest peers know popular cyborg-like characters from different ages. It was supposed that old versions of cyborgs are mainly unknown, whereas new ones are perceived as normal.

However, the data revealed a more complicated picture, which is shown in a corresponding interpretation considering the thesaurus constructs of young people living in various regions of modern Russia. Young people utilize different sources of human "enhancement" technologies, but without showing the difference in attitude towards them. It is not professional but social and cultural factors that have an effect here. Young people from various regions of Russia do not normally have differences in their judgment of human "enhancement" technologies. Medical and biology students see the ways of human modification just in the same way as students and professionals in other fields do. The young consider themselves not competent enough to undertake the burden of human "enhancement". Nevertheless, about one third of the respondents acknowledge the special role that youth play in the prospects of formation of the new human.

Keywords: transhumanism; biosociology; youth, genetic engineering; cyborg; Golem; Frankenstein; professor Dowell; Terminator; Robocop

\section{REFERENCES}

Briukhonenko, S. S. and Chechulin, S. I. (1926) Opyty po izolirovaniiu golovy sobaki (s demonstratsiei pribora). In: Trudy II Vsesoiuznogo s'ezda fiziologov. Leningrad, Glavnauka. Pp. 289-290. (In Russ.).

Zakharov, N. V. (2008) Shekspirizm russkoi klassicheskoi literatury: tezaurusnyi analiz. Moscow, Mosk. gumanit. un-t Publ. 320 p. (In Russ.).

Kol'tsov, N. K. (1922) Uluchshenie chelovecheskoi porody. Russkii evgenicheskii zhurnal, vol. 1, issue 1, pp. 1-27. (In Russ.).

Lamazhaa, Ch. K. (2012) Tezaurusnyi podkhod v tuvinovedenii. Znanie. Ponimanie. Umenie, no. 2, pp. 38-45. (In Russ.). Russ.).

Lukov, V. A. (2012) Teorii molodezhi: Mezbdistsiplinarnyi analiz. Moscow, Kanon+. 527 p. (In

Lukov, V. A. (2016) Biotekhnologii budushchego v otsenkakh molodezhi. In: Rabochie tetradi po bioetike. Vyp. 23: Gumanitarnyi analiz biotekbnologicheskikb proektov «uluchsbeniia» cheloveka : sb. nauch. st., ed. B. G. Iudina. Moscow, Moskov. gumanit. univ. publ. Pp. 132-255. (In Russ.).

Lukov, V. A. and Lukov, Vl. A. (2008) Tezaurusy: Sub' ektnaia organizatsiia gumanitarnogo znaniia. Moscow, Nats. in-t biznesa. 784 p. (In Russ.).

Lukov, V. A. and Lukov, Vl. A. (2013) Tezaurusy II: Tezaurusnyi podkbod k ponimaniiu cheloveka i ego mira. Moscow, Nats. in-t biznesa. 640 p. (In Russ.).

Lukov, V. A. and Pavlov, A. V. (2015) Konstruirovanie cheloveka v svete tezaurusnoi kontseptsii molodezhi. Informatsionnyi gumanitarnyi portal «Znanie. Ponimanie. Umenie», no. 4 [online] 
Available at: http://zpu-journal.ru/e-zpu/2015/4/Lukov_Pavlov_Constructing-Man/ (access date: 10.02.2017). (In Russ.).

Lukov, Vl. A. (2006) Predromantizm. Moscow, Nauka. 683 p. (In Russ.).

Liapunov, B. V. (1967) Aleksandr Beliaev. Kritiko-biograficheskii ocherk. Moscow, Sov. pisatel'. 27 p. (In Russ.).

Sotsiogumanitarnoe obespechenie proektov personalizirovannoi meditsiny: filosofskii aspekt (2014) / Belialetdinov, R. R., Grebenshchikova, E. G., Kiiashchenko, L. P., Popova et al. Znanie. Ponimanie. Umenie, no. 4, pp. 12-26. (In Russ.).

Filipchenko, Iu. A. (1924) Puti uluchsheniia chelovecheskogo roda: Evgenika. Moscow, Leningrad, Gosizdat. 190 p. (In Russ.).

Frankenshtein. Vikipediia. Svobodnaia entsiklopediia [online] Available at: https://ru.wikipedia.org/wiki/Frankenshtein (access date: 15.02.2017). (In Russ.).

Iudin, B. G. (2016) Tekhnonauka i «uluchshenie» cheloveka. Epistemology \& Philosophy of Science, vol. XLVIII, no. 2, pp. 18-27. (In Russ.).

Baer, E. R. (2012) The Golem Redux: From Prague to Post-Holocaust Fiction. Detroit, Wayne State University. 240 p.

Clynes, V. E. and Kline, N. S. (1960) Cyborgs and Space. Astronautics, Sept., pp. 26-27, 74-76.

Dinello, D. (2013) Technophobia!: Science Fiction Visions of Postbuman Tecbnology. Austin, University of Texas Press. 329 p.

Frankenstein. Wikipedia. The free encyclopedia [online] Available at: https://en.wikipedia.org/ wiki/frankenstein (access date: 15.02.2017).

Garrett, R. (2010) Part man. Part machine. All cop. The future of law enforcement. LEPN. On the Street, May 1 [online] Available at: http://www.officer.com/article/10232717/part-man-part-machine-all-cop-the-future-of-law-enforcement (access date: 15.02.2017).

Gross, R. and Riedel E. (Hrsg.) (2008) Superman und Golem. Der Comic als Medium jüdischer Erinnerung. Frankfurt, Jüdisches Museum. 48 p. (In Germ.).

King, P. (1986) Hollywood turns to Monessen steel plants in filming 'PoboCop'. The Pittsburgh Press, October 29. P. 6.

Markoff, J. (1990) Ideas \& Trends; Art Invents A Jarring New World From Technology. The New York Times: Week in Review. November 25.

Mayer, N. (2014) Ein Golem aus Plastilin geistert durch die Salzburger Festspiele. Die Presse, 24.08. (In Germ.).

Submission date: 20.02.2017.

Ауков Валерий Андреевич - доктор философских наук, профессор, директор Института фундаментальных и прикладных исследований Московского гуманитарного университета, заслуженный деятель науки Российской Федерации, Адрес: 111395, Россия, г. Москва, ул. Юности, д. 5. Тел.: +7 (499) 374-75-95. Эл. адрес: v-lukov@list.ru

Lukov Valery Andreevich, Doctor of Philosophy, Professor, Director, Institute of Fundamental and Applied Studies, Moscow University for the Humanities; Honoured Scientist of the Russian Federation. Postal address: 5 Yunosti St., Moscow, Russian Federation 111395. Tel.: +7 (499) 374-75-95. E-mail:v-lukov@list.ru 